\title{
モルモット蝸牛内・外リンパ圧の測定
}

\author{
吉 田雅 文・上 村 卓 也
}

\section{Measurement of Endolymphatic and Perilymphatic Pressure in the Guinea Pig Cochlea}

\author{
Masafumi Yoshida and Takuya Uemura \\ (Kyushu University)
}

Hydrostatic pressure in the endolymph and perilymph was measured by a servocontrolled micropipette system in guinea pigs anesthetized with pentobarbital. During and after 3 minutes of anoxia, endolymphatic pressure showed changes similar to those observed in systemic arterial pressure and cochlear blood flow. Fine fluctuations with influences of heartbeat and respiration were observed in the endolymphatic pressure. These facts indicate that the system is applicable for the accurate measurement of inner ear pressure, especially of endolymphatic pressure. In guinea pigs with middle ear filled with a saturated sodium chloride solution, both endo- and perilymphatic pressure measurements showed a gradual decline for 15 minutes and a slow recovery during the next 25 minutes. These pressure changes indicate that water is transferred through the semipermeable membrane of the inner ear due to modified osmolarity. The absence of a pressure gradient between the two fluids during the period of observation suggests that Riessner's membrane is not stiff.

\section{は じめに}

内耳液の静水圧に関する研究は, イオン濃度や浸透圧などの研究と並んで, 内耳液代謝の異常に よって起こると考兄られている内耳障害，たとえばメニェール病などの病態を知る上で重要である. これまでに, 直接電気圧力計に接続したカニューレを内耳に挿入する方法で観察された, 外リンパ 圧に関する知見は数多く報告されている ${ }^{1-5)}$.しかし，従来のこの方法で内リンパ圧を測定するには， 技術的に問題がある.

われわれは，毛細血管内の血圧測定のために開発された servo-controlled micropipet system ${ }^{6}$ を用い，モルモットに执いて内リンパ拈よび外リンパの静水压の測定を行っている．本稿では， anoxia 負荷ならびに飽和食塩水の中耳腔への注入の，内耳液圧に及ぼす影響について報告する.

\section{実 験 方 法}

実験には，体重 $200 \mathrm{~g}$ から $400 \mathrm{~g}$ の耳谢 正常な黒目モルモットを使用した。図 1 に, 測
定の block diagram を示す. 内耳液圧の測定 には, WP-Instrument Model 900 Micropres- 


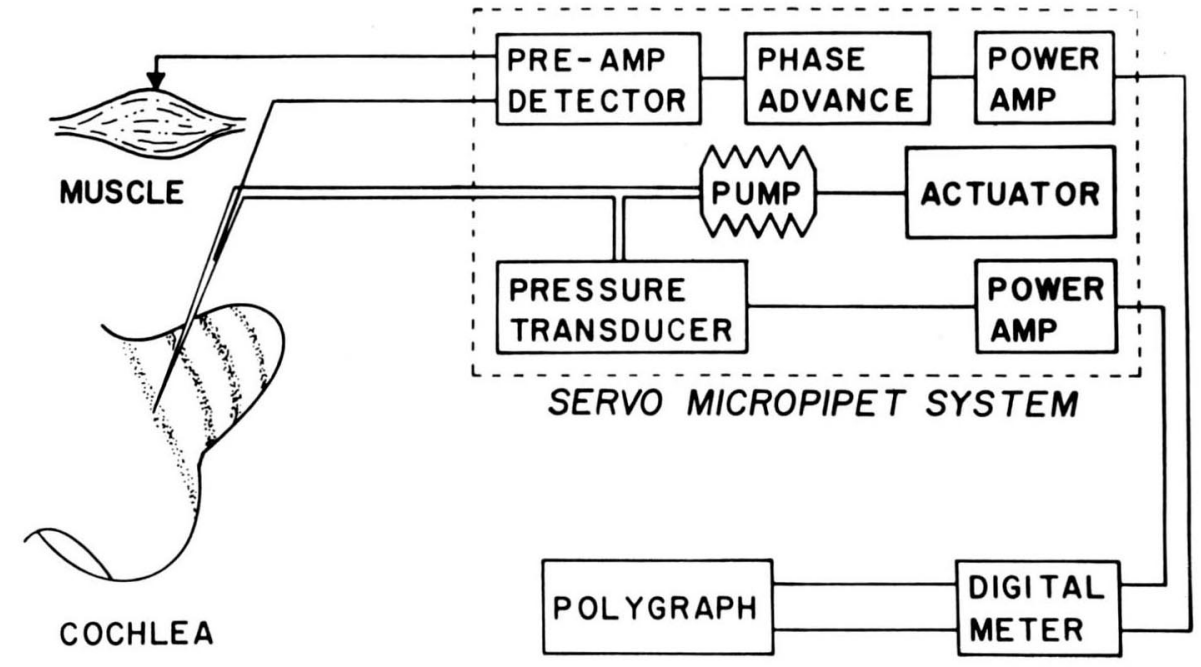

図 1 モルモット蝸牛内・外リンパ压測定の block diagram.

sure System を用いた.この system は, 先

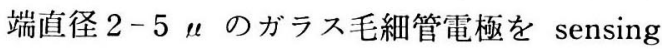
element として，微少な体積腔内の静水圧と電 位を同時に測定するもので，その原理の詳細は 既に報告した7).

動物は pentobarbital $40 \mathrm{mg} / \mathrm{Kg}$ 腹腔内投 与により麻酔し, tubocurine chloride $6 \mathrm{mg}$ / $\mathrm{Kg}$ 筋注による筋弛緩下に, 人工呼吸を行った. ventral approach で中耳骨胞を開き，蝸牛基 底回転の骨壁を薄く削り，中央階または鼓室階 に相当する部に, 直径20-50 $\mu$ の小孔を作製し た.この小孔より, micropressure system に 接続した毛細管電極を, micromanupulator を 用いて螖牛内に刺入した.

一匹の動物からは, 内リンパまたは外リンパ いづれか一方の静水圧を測定した. 内リンパ圧 の測定では, ラセン鞄帯および血管条がシール

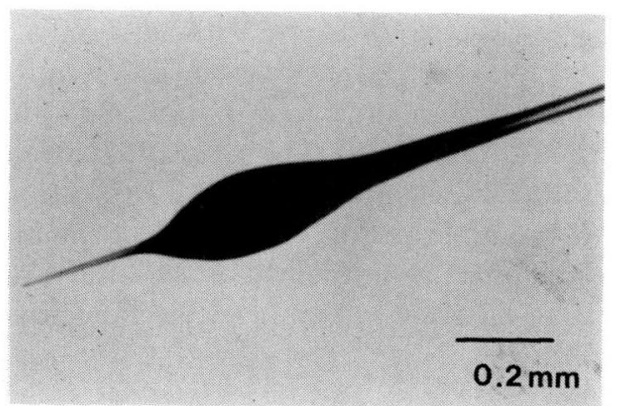

図 2 外リンパ压の測定に用いた, 先端から約 $400 \mu$ にシールを持つ pipet.

の役割を果し, リンパ液の漏れは認められなか った. 一方, 外リンパ压の測定に際しては, 先 端より約 $400 \mu$ の部にシールを有する特殊な pipetを用いた（図 2 ）。静水圧と直流電位は， polygraph 上に記録するとともに, digital meter で直読した.

\section{実 験 結 果}

1) anoxia

3 分間の人工呼吸停止による anoxia の, 内 リンパ圧に及ぼす影響を観察した。

図 3 に示す一例のように, 内リンパ圧は anoxia の開始後徐々に上昇し，その解除後に 急激な一過性の上昇を示した後, 正常の值に戻 っていった. 5 匹のモルモットにおける anoxia 解除後の圧上昇は, $12.1 \pm 2.6 \mathrm{mmHg}$ (平 


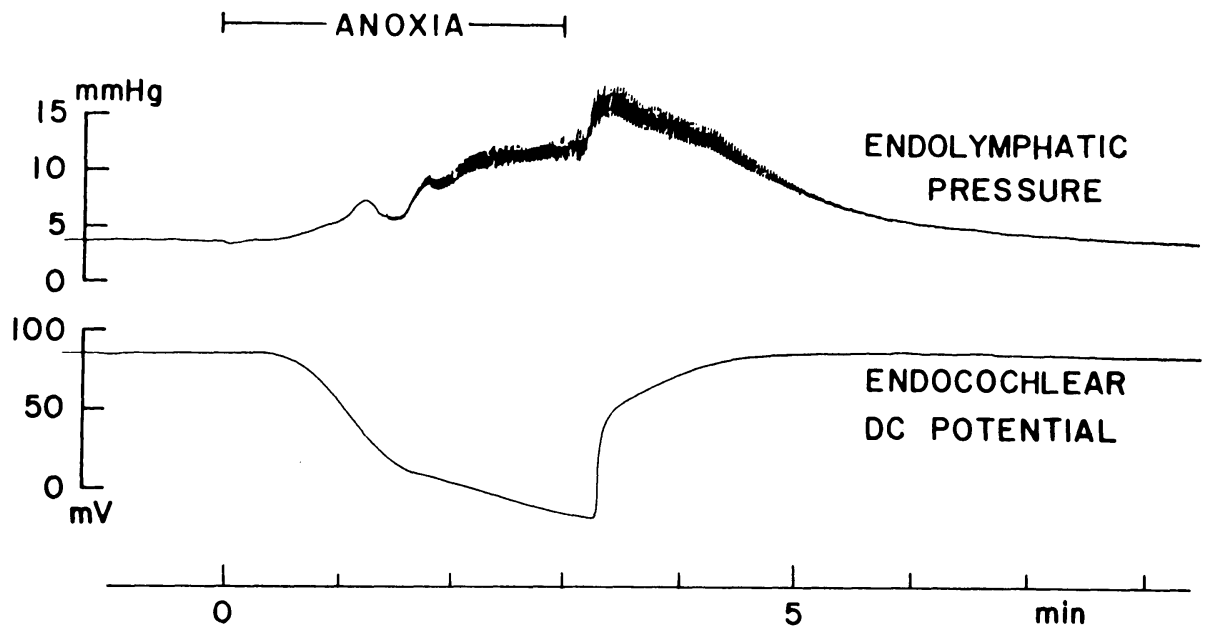

図 33 分間の anoxia 負荷による内リンパ圧と蝸牛内直流電位の変化.
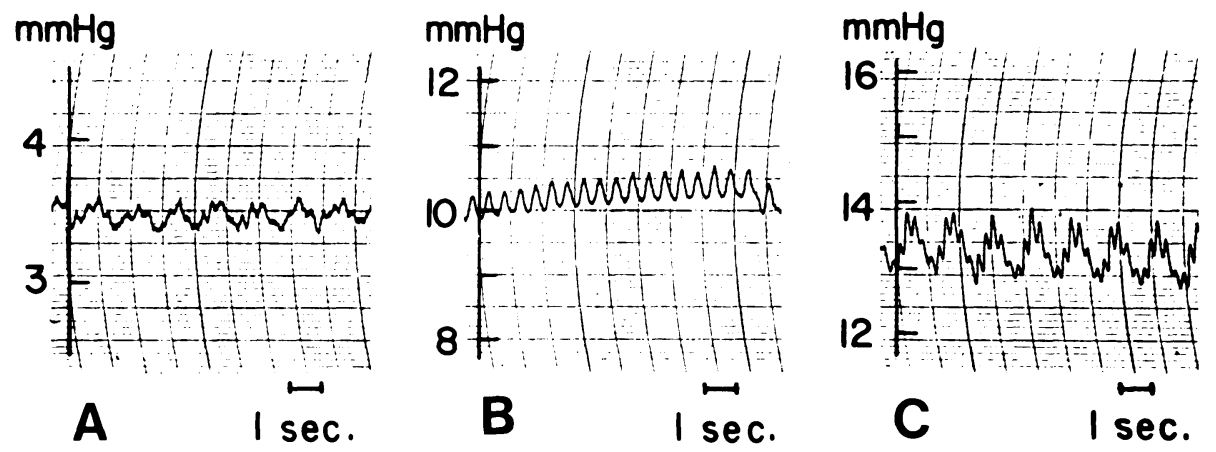

A : anoxia 負荷前, B : anoxia 開始 2 分後, C : anoxia 解除 1 分後.

図4 内リンパ圧の，呼吸と心拍による微細な変動.

均土標準偏差，以下同じ）であり，上昇のピー クは解除後 $16 \pm 6$ 秒に認められた。図 4 に，呼 吸および心拍による内リンパ圧の微細な変動を 示す. anoxia により, 図 4 Aにみられた呼吸 性の変動は消失し，徐脈となった心拍による変 動のみが観察された（図 $4 \mathrm{~B}$ ). anoxia の解除 後には, 呼吸と心拍による変動はともに増強さ れていた（図 $4 \mathrm{C}$ ).

同時に観察された蝸牛内直流電位（EP）は， anoxia の開始後減少し, 3 分後では $-28.5 \pm$ $10.0 \mathrm{mV}$ に達し, anoxia の解除とともに急速 に回復した。
2 ）飽和食塩水の中耳腔注入

飽和食塩水約 $0.1 \mathrm{ml}$ を, 中耳腔へ注入した 時の, 内・外リンパ圧の変動を観察した. 注入 は安定した圧が 5 分間以上記録されることを確 認した後, あらかじめ蝸牛空近くまで挿入して おいたポリエチレンチューブを通して行った。

図 5 に注入による内リンパ圧と EP の変動 の一例を，図6にそれぞれ 5 匹の動物から得ら れた内・外リンパ圧の平均を示す。注入前の圧 は内リンパ $3.0 \pm 0.6 \mathrm{mmHg}$ で，外リンパ 3.2 $\pm 0.9 \mathrm{mmHg}$ であり, 両者の間には, $\mathrm{t}$ 検定で 有意の差はなかった（p>0.6）. 飽和食塩水の 


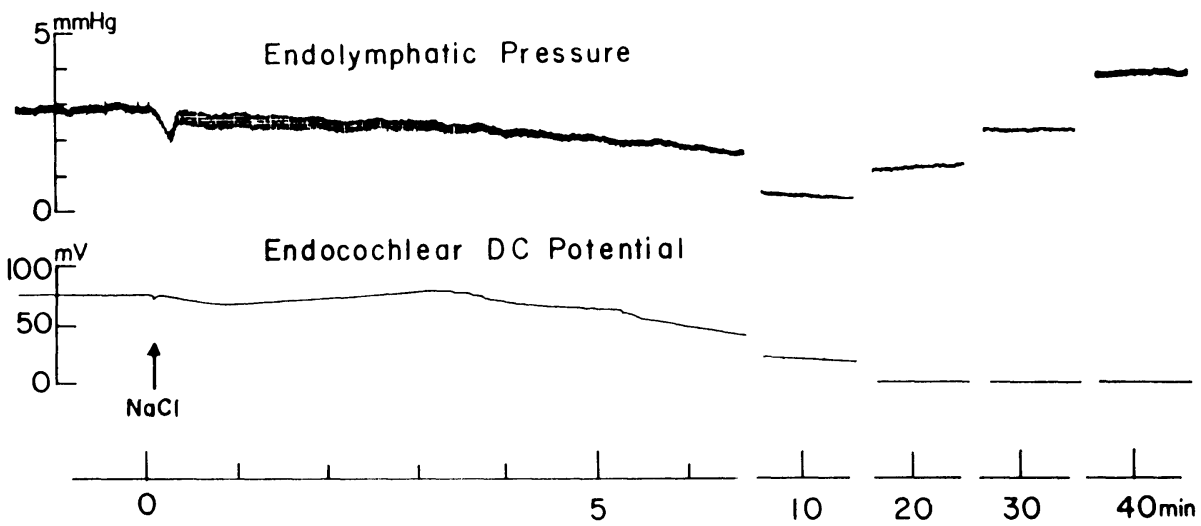

図 5 飽和食塩水の中耳腔注入による内リンパ圧と蝸牛内直流電位の変化.

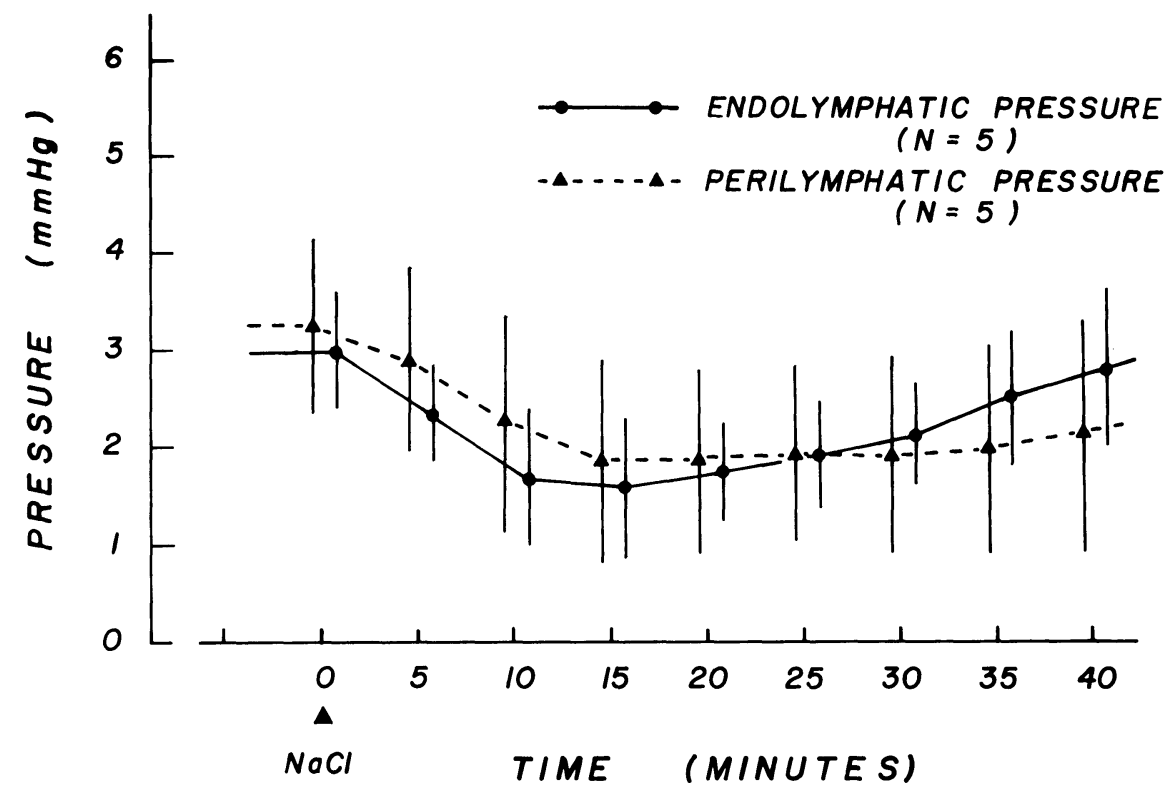

図 6 飽和食塩水の中耳腔注入による内・外リンパ圧の变化. それぞれ 5 匹のモルモ ットでの平均值と標準偏差を示す.

注入に続いて，内・外リンパ圧はともに徐々に 低下し，約15分後に最低のレベルに達した。内 リンパ压低下の 最大值は平均で $1.4 \pm 1.0 \mathrm{~mm}$ $\mathrm{Hg}$ であり,外リンパ圧のそれは $1.4 \pm 0.5 \mathrm{~mm}$ $\mathrm{Hg}$ であった．両者の間に差は認められなかっ た $(\mathrm{p}>0.9)$. その後両りンパ圧はゆっくりと上 昇していったが，この実験では外リンパに比
ベ，内リンパ圧の回復が先行する傾向が認めら れた. しかし注入後40分では，内・外リンパ压 はそれぞれ $2.8 \pm 0.8 \mathrm{mmHg}$ と $2.1 \pm 1.2 \mathrm{~mm}$ $\mathrm{Hg}$ であり, 両者の差は統計的に有意でなかっ た（p>0.3）.

飽和食塩水注入前の EP は, 5 例の平均で $78.0 \pm 7.8 \mathrm{mV}$ であった. 注入後 2 分から 5 分 
にかけて数ミリボルトのオーバーシュートを示 した後，EP は低下し約 30 分で最低值 $3.7 \pm 2.1$

\section{考}

内耳液圧に関する研究は，これまで外リンパ 圧をその主な対象として数多く行われてきた。

1958年に Weille ${ }^{1)}$ が容量型トランスデューサ 一を用い，また1965年に中島 ${ }^{2)} か ゙ ， 1968$ 年には Martinez ${ }^{3)}$ が歪ゲージ型トランスデューサーを 用いた内耳液の測定を報告している.

しかし, 従来の方法を用いて内耳圧, 殊に内 リンパ圧の測定を行うには，技術的な問題があ る. Beentijes ${ }^{4)}$ は, カニューレを直接圧トラ ンスデューサーに接続する方法では, 内耳に挿 入するカニューレの先端直径が数十 $\mu$ 以下で あると，心拍や呼吸に伴う圧の微細な動摇が観 察できないことを報告している，一方，内リン パ液の量はモルモットで $0.002 \mathrm{ml}$ とされてお $\eta^{8)}$, このょらに微少な体積腔に直径数十 $\mu$ 以 上のカニューレを挿入すれば, 蝸牛管の損傷や 圧自体に及ぼす影響は無視できない。

1975年に Angelborg9) が，また1981年には Nagahara $^{10)}$ が, Weiderhielm ${ }^{6)}$ により初めて 生理学実験に応用された servo-controlled micropressure system を使用し，外リンパ圧に 関する研究を報告している，われわれは同じ原 理に基づいて開発された micropressure system を，外リンパだけでなく内リンパ圧の測定 に応用した. この方法には, 電気圧力計を用い た従来の方法に比べ，いくつかの利点がある. 第一に, 測定系の volume displacement は0 に等しく, 内リンパのような微量の液体の圧変 化が正確に測定できる. 次に，カニューレの先 端直径が $5 \mu$ 以下と小さく, 挿入による内耳へ の影響が少ない。をた，同時に測定される $\mathrm{EP}$ により，カニューレの先端が中央階に位置して いること，および蝸牛管に損傷がないことを容 易に確認できる.

人工呼吸の停止による anoxia の負荷で, 内 リンパ圧は徐々に上昇し, anoxia の解除後に
$\mathrm{mV}$ に達した. その後の10分間には電位の変化 はなく，極性の逆転は認められなかった。

\section{按}

一過性の急な上昇を示し, その後ゆっくりと負 荷前の值へと戻っていった．この圧の変化は, 全身血圧の変化と類似しており ${ }^{11)}$, その微細な 変動は impedance plethysmography により 測定された蝸牛血流のそれとも一致していた ${ }^{12)}$.

これらの事実から, 内耳圧は従来の報告にみ られる髄液圧 ${ }^{5)}$, 全身血圧 ${ }^{10)}$ の影響と同時に, 局所の血流の影響を直接に受けていると考えら れた. 同時に, 図 4 に示したように, 内リンパ 圧の微細な変動が, anoxia 負荷前後において 変化することも記録されていた. また，蝸牛管 に損傷があると認められないとされる anoxia 時の負の $\mathrm{EP}$ も， 3 分後には約 $-30 \mathrm{mV}$ の值 を示した. 従ってわれわれの用いた測定装置に より, 内リンパ圧の正確な測定が可能であると 結論した.

Arslan $^{13)}$ は, モルモット中耳腔に飽和食塩 水を注入することにより, 早期に执いての注入 側向きと，それに続く反注入側向きの二相性眼 振が認められることを報告し, この実験的内耳 障害がメニエール病のめまい発作に類似するこ とを指摘するとともに, 内耳液の浸透圧変化に 基づく水の移動を, その障害の機序として重視 した. Molinari ${ }^{14)}$ は, 蝸牛空に $\mathrm{NaCl}$ の結晶 を置くと，30分後には内・外リンパの $\mathrm{Na}, \mathrm{K}$ イオン濃度が著明に上昇し, 180 分後には正常 に近い值まで減少することを，また Huangf $\mathrm{u}^{15)}$ らは, 外リンパKイオン濃度上昇のピークが, 投与後15分にあることを報告している.この内 耳液イオン濃度の上昇が, 浸透圧による水の移 動に基づくものであるとすれば, 内耳から高張 な液で満たされた中耳腔へ水の出ていく早期に は内耳压の低下が, 周囲組織から高張となった 内耳へ水の入ってくる後期には圧の上昇が考え られる。

われわれの実験では, 飽和食塩水の中耳腔注 
入により，内・外リンパ压はともに低下し約 15

分で最低となり，その後徐々に上昇していっ

た. これは, 予想された変化と時間的にも一致

しており, 内耳での速やかな水の移動が裏付け

られた。 また, 組織学的に内リンパ腔の collapse があり, Reissner 膜の変位が報告されて

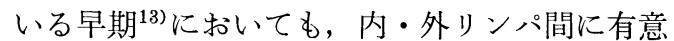
の圧差は観察されなかった. このことから， Reissner 膜の stiffness は極めて小さく, 内 耳液の代謝異常によりその体積に変動がおこる 時, Reissner 膜は容易に伸展され, hydrops または collapse が形成されると考えられた。

\section{ま と め}

1 ） servo-controlled micropipet system を用い，モルモット螖牛内リンパおよび外リンパ静水圧 の測定を行った.

2 ）人工呼吸の停止による 3 分間の anoxia で，内リンパ圧は全身血圧と平行した変化を示した. 心拍や呼吸によるその微細な変動は, 内耳液流のそれと一致していた.

3 ）飽和食塩水を中耳腔に注入することにより, 内・外リンパ圧はともに低下し, 約15分で最低值 に達し，その後徐々に上昇した。注入後40分間の観察では，内・外リンパ間に圧差は認められな かった.

文

1) Weille FL, et al: Pressure of the labyrinthine fluids. Ann Otol Rhinol Laryngol 67: 858 868, 1958.

2 ) 中島恒彦: 内耳圧変動に関する実験的研究. 耳鼻 11 : 補 4 : 153 168, 1965.

3) Martinez DM: Simultaneous measurement of endolymphatic and perilymphatic fluid pressures before and during anaphylaxis and associated changes in cerebrospinal fluid, venous and arterial pressures. Acta Otolaryngol [Suppl] 238: 1 53, 1968.

4) Beentjes $\mathrm{BJ}$ : The cochlear aqueduct and the pressure of cebrospinal and endolabyrinthine fluids. Acta Otolaryngol $73: 112 \sim 120,1972$.

5 ) Carlborg BIR and Farmer JC: Transmission of cerebrospinal fluid pressure via the cochlear aqueduct and endolymphatic sac. Am J Otolaryngol $4: 273 \sim 282,1983$.

6 ) Weiderhielm CA, et al: Pulsatile pressure in the microcirculation of frog's mesentery. Am J Physiol 207 : 173 176, 1964.

7 ) Yoshida Mland Lowry LD: Hydrostatic pressure measurement of endolymph and perily-
献

mph in the guine pig cochlea. Am J Otolaryngol 5 : 159 165, 1984.

8) Johnstone BM and Sellick PM: The peripheral auditory apparatus. Q Rev Biophys 5: 1 $\sim 57,1972$.

9) Angelborg C and Agerup B: Glycerol effects on the perilymphatic and cerebrospinal fluid pressure. Acta Otolaryngol 79: 81 87, 1975.

10) Nagahara $K$, et al : Experimental study on the perilymphatic pressure. Am J Otol 3: 1 8, 1981.

11）吉田雅文, 他：モルモット蝸牛内リンパ圧と EP の同時記録の試み. 基礎耳科 $12: 181 \sim 183$, 1981.

12) Morimitsu $T$, et al: Behavior of the cochlear blood flow. Ann Otol Rhinol Laryngol 74: $22 \sim 32,1965$.

13) Arslan $M:$ Modification of the osmotic pressure of perilymph and endolymph: an hypothesis of the pathogenesis of Meniere's disease. Acta Otolaryngol $67: 360 \sim 377,1969$.

14) Molinari GA: Alteration of inner ear mechanisms resulting from application of sodium 
chloride on the round window membrane. Ann Otol Rhinol Laryngol 81: 315 322, 1972.

15) Huangfu $M$, et al : Dynamics of the flow of perilymph in the cochlea of the guinea pig.
Arch Otolaryngol 108: 535 538, 1982. 別刷請求先：吉田 雅文 干812 福岡市東区馬出3-1-1 九州大学医学部耳鼻咽喉科学教室 